\title{
LA OBRA DEL GRABADOR COMPOSTELANO JUAN CRISOSTOMO LOPEZ EN EL MUSEO DE PONTEVEDRA
}

\author{
por \\ COVANDONGA LOPEZ DE PRADO NISTAL
}

\section{LA IDENTIDAD DEL GRABADOR: JACINTO LOPEZ O JUAN CRISOSTOMO LOPEZ}

A Fermín Bouza Brey debemos el haber desvelado la identidad de este grabador que trabajó en Compostela en los últimos años del S. XVIII y primeros del XIX ${ }^{1}$, cuya obra, debido a una mala lectura de M. Murguía ${ }^{2}$, venía siendo atribuida a un tal Jacinto López inexistente como grabador. Error en el que insisten sucesivamente E. Mayer ${ }^{3}$, Couselo Bouzas ${ }^{4}$, y Filgueira Valverde, quien atribuye la estampa de la Dolorosa de la Parroquia de San Miguel de Santiago a Juan Domingo López, grabador dieciochesco compos-

\footnotetext{
' F. BOUZA BREY: El grabador y platero compostelano Angel Piedra (1735-1800) Cuadernos de Estudios Gallegos, T. XXV 1960, pág. 177-178.

Idem: Los grabadores compostelanos del siglo XVIII. Compostelanum., vol. IX, no 4, 1964, pág. 205.

${ }^{2}$ M. MURGUIA: El arte en Santiago. Madrid, 1884, pág. 218.

${ }^{3}$ E. MAYER: Prioridad de un artista santiagués respecto al perfeccionamiento del grabado en madera. Santiago, 1903, pág. 18.

${ }^{4}$ J. COUSELO BOUZAS: Galicia Artistica en el S. XVIII y primer tercio del XIX. Santiago, 1932, pág. 423-424.
}

"CUADERNOS DE ESTUDIOS GALLEGOS", Tomo XL, Fascículo 105, Santiago 1992. 
telano del cual solo se conoce una estampa de la Virgen de la Merced ${ }^{5}$. En 1966 Benezit insiste en la identificación errónea ${ }^{6}$, y aun, en 1986 se nombra a Jacinto López en una monografía sobre Julio Prieto Nespereira ${ }^{7}$. El único que parece hacerse eco del descubrimiento de Bouza Brey es Antonio Gallego en su Historia del Grabado en España, publicada en 1979.

Fue la estampa de la Dolorosa la que indujo al error pues, al ser retocada por Isidoro Brocos en el S. XIX, éste superpuso su nombre al de nuestro grabador, dando lugar a una mala lectura de la firma.

En el resto de sus obras, así como en el ejemplar sin retocar que posee el Museo, firma como Ioans Lopez con la excepción de la xilografía de la Virgen de Belen de San Benito de Santiago, en donde la firma se limita al apellido.

Se desconocen los datos referentes a su formación y a su vida en general. En cuanto a la primera, M. Murguia ${ }^{6}$, Couselo Bouzas ${ }^{7}$ y Filgueira Valverde ${ }^{8}$, lo consideran discípulo de Angel Piedra, quizás basándose en el hecho de que Juan Crisóstomo López grabara un San Felipe Neri en el reverso de la plancha de cobre sobre la que Angel Piedra abriera una imagen del mismo santo. Pero no tenemos pruebas objetivas suficientes que nos permitan mantener dicha afirmación.

El único documento en el que figura su nombre completo relacionado con el grabado, es en una partida que Bouza Brey localizó en los libros de la Cofradía de las Animas de Santiago 9:

Entrada y indulto de Maiordomo de Dn. Juan Crisostomo Lopez.En veintiuno de Diciembre de ochenta y nueve, se admitio entrar el sobredicho yndultado de Mayordono y todos cargos por haber deliniado y abierto la nueva lamina de los retratos de las Animas como igualmente la tarjeta de las cedulas y para que conste lo firmo.- Liñeyra (ribricado). Juan Chrysostomo Lopez (rubricado).

Quedaba pues con este documento aclarada la identidad de uno de los

\footnotetext{
5 J. FILGUEIRA VALVERDE: Grabados compostelanos. Pontevedra, 1949, pág. 15.

${ }^{6}$ En la colección del Museo de Pontevedra: num. $\mathrm{R}^{\mathrm{o}}$ 1669-23.

${ }^{7}$ E. BENEZIT: Dictionaire critique et documentaire des peintres, sculpteurs, dessinateurs et graveurs. Saint Ouen, 1966, pág. 630.

${ }^{8}$ Prieto Nespereira. Santiago: Consellería de Cultura, 1986.

${ }^{9}$ M. MURGUIA: op. cit., pág. 218.
} 
grabadores mas prolificos de finales del S. XVIII en Compostela. Nos queda a nosotros ahora la tarea de analizar su obra.

\section{UNA PROLONGACION DEL GUSTO ROCOCO EN EL GRA- BADO COMPOSTELANO}

A caballo entre los últimos coletazos del rococó y las nuevas tendencias neoclásicas, Juan Crisóstomo López no supo desprenderse de un estilo decadente y acabado, prolongándolo hasta el límite del siglo. No fue desde luego el único en Compostela que se resistió a las novedades ${ }^{10}$, pero otros grabadores contemporáneos suyos terminaron por ceder a las nuevas tendencias, que venían siendo promocionadas desde el último tercio del siglo por las Academias de Bellas Artes.

Frente a grabadores como Angel Piedra, Melchor de Prado o Luis de la Piedra, Juan Crisóstomo López resulta un grabador muy mediocre en el círculo compostelano, aunque sus estampas debieron de tener bastante éxito -a juzgar por el número de grabados suyos que se conservan- entre una clientela popular formada por particulares, como se demuestra con la presencia reiterada de la frase a expensas de un devoto, conventos y cofradias que solicitan a los grabadores locales la reproducción de imágenes de devoción popular a las que dedican preferentemente culto, acompañadas en muchas ocasiones por las indulgencias, concedidas por el arzobispo u otro prelado, a quien rezase ante la imagen.

Mal dibujante y con poca soltura en el grabado, podríamos considerarlo, mas que como un artista, como un artesano de la estampa de devoción, género éste al que se limita su obra. Cultivó tanto el grabado en madera como en cobre, trabajando con el buril y la punta seca, técnicas en las que realizó sus mejores grabados. Estos se caracterizan por la utilización del punteado, fundamentalmente para el sombreado de rostros y partes desnudas del cuerpo, llegando a obtener resultados aceptables en la estampa de la Dolorosa de la Parroquia de San Miguel.

En los años en los que nos consta que trabaja J. Crisóstomo López, el gusto rococó había sido sustituido por los presupuestos neoclásicos, con absoluto rechazo de las florituras y de la decoración recargada, alejada de

${ }^{10} \mathrm{~J}$. COUSELO BOUZA; op. cit. pág. 425.

"CUADERNOS DE ESTUDIOS GALLEGOS", Tomo XL, Fascículo 105, Santiago 1992. 
cualquier esquema rígido, que había introducido en España la moda francesa en el segundo tercio del siglo.

Si es cierto que en Galicia el gusto barroco se prolongó durante las últimas décadas del siglo, no es menos cierto que en 1778 Angel Piedra realizaba una estampa de la imagen de San Buenaventura de la Iglesia de San Francisco de Santiago en donde renuncia e ese decorativismo orgánico y se adscribe a la tendencia neoclásica. Sin embargo, aún diez años más tarde, Juan Crisóstomo grabará una estampa de $\mathrm{N}^{\mathrm{a}} \mathrm{S}^{\mathrm{a}}$ de Pastoriza donde se hace patente el gusto rococó, tanto en la orla como en el tratamiento del tema.

En la orla renuncia a la línea recta, evocando con el movimiento encontrado de las curvas el rítmo fluído del oleaje tan del gusto de las décadas anteriores. El motivo de la rocalla ya había sido utilizado en el grabado compostelano por Jacobo de la Piedra, entre otros. Este fue desarrollado con gran acierto y mayor libertad por Angel Piedra en los espléndidos marcos y orlas de ritmos fluídos y contrapuestos, como podemos apreciar en las estampas de San Pedro, Santo Tomás, o el grabado conmemorativo de la reedificación de la Iglesia de Pontedeume, en donde supera con mucho, tanto en dominio técnico como en riqueza decorativa, a nuestro grabador.

Las orlas de Juan Crisóstomo López resultan, dentro de su organicidad, rígidas, con poca soltura en el diseño de curvas y contracurvas, y faltas de imaginación en la transformación de elementos.

Dos versiones nos ofrece de la Divina Pastora, tema campestre muy del gusto de la época, y cuyo culto estará en auge en el siglo XVIII, debido al esfuerzo realizado por los capuchinos ${ }^{11}$, asi como al caracter gracioso y amable de su inocografía, que encaja perfectamente con ese ideal bucólicopastoril que tanto éxito tiene en las cortes dieciochescas europeas, disfrazando a la Virgen o a la cortesana de ingenua y elegante pastora, tema que vale tanto para una estampa religiosa, una pieza de porcelana o una pintura de salón.

De estas dos versiones realizadas por el grabador compostelano, una se mantiene dentro de la tendencia barroca más clásica y la otra responde plenamente al gusto rococó: en este último se representa la escena pastoril sobre un paisaje campestre enmarcado con una orla de rocalla, mientras que en el primero el tema se encierra en una hornacina barroca con la imagen

${ }^{11}$ P. Fco. BACAICOA: La Virgen como Pastora. Archivo Español de Arte, t. XXX, no 119, 1957, pág. 242.

"CUADERNOS DE ESTUDIOS GALLEGOS", Tomo XL, Fascículo 105, Santiago 1992. 
acompañada de los atributos indispensables.

Ambas fueron grabadas el mismo año, sobre las dos caras de una misma plancha de cobre. Son dos estampas de la Virgen Pastoriza que se venera en la Capilla de la Parroquia de San Miguel de Santiago, realizadas a expensas de dos devotos, e incorporando en la leyenda las consabidas indulgencias concedidas por el arzobispo de Santiago. En ellas el dibujo resulta torpe, y sin gradaciones tonales en el grabado.

Otra característica inherente al gusto rococó, como es el evolucionar de los elementos decorativos en una continua transformación ambivalente, se hace patente en el grabado a buril de la Dolorosa de la Parroquia de San Miguel de Santiago, realizado en 1798, del cual posee el Museo dos ejemplares, uno de ellos es un original sin retocar.

En esta estampa la imagen de la Virgen centra la composición rodeada por los atributos de la Pasión, que sustituyen, en cierto modo, a la orla. Esta parece arrancar en el ángulo inferior izquierdo, hacia arriba con un tallo, y prolongándose con un juego de curvas y contracurvas recortando la ilustración, en el margen inferior. Mientras, por los lados, la orla se construye con los atributos estratégicamente colocados en torno a la imagen, formando parte del tema central pero al mismo tiempo constituyendo el marco, jugando asi un papel decorativo y temático a la vez.

En cuanto a la Virgen, es la imagen más exquisita dentro de la obra que conservamos de este grabador. Aqui la rigidez del buril de Juan Crisóstomo desaparece, se aprecia la caida pesada del paño, las dobleces mórbidas de los pliegues, y la suavidad de la línea se trasluce en la delicadeza de la imagen, que adopta un gesto recogido y elegante. La transición de las zonas de clarooscuro se hace de forma mas suave, explotando así, con mayor éxito, las cualidades que ofrece la técnica del buril frente a la punta seca o a la xilografía.

En la estampa del Timpano de la Virgen de Belen de San Benito de Santiago estamos ante un grabado en madera en donde no solo desaparece la rocalla, sino que ademas esta ausente todo motivo ajeno a la escena de la Epifanía, representada entre cortinajes recogidos a los lados y cerrada por una sencilla línea arqueada. Sobre esta sobresale una discreta gloria de rayos y nubes flanqueada por una pareja de angeles que sostienes cada uno una filacteria. El grabador ha prescindido aqui de la figura del donante que en el relieve aparece arrodillado a la izquierda de la Virgen.

No existe pues, ninguna concesión al decorativismo barroco ni en el marco, que consiste en una simple línea sin orla, ni en la leyenda compren-

"CUADERNOS DE ESTUDIOS GALLEGOS", Tomo XL, Fascículo 105, Santiago 1992. 
dida dentro de las líneas del margen bajo la ilustración. Esta austeridad debemos achacarla a una evolución en el estilo del artista pues estamos ante una xilografía que pertenece ya a la segundo década del S. XIX.

No encontramos aquí la firma habitual de Juan Crisóstomo, pero si podemos comprobar que los caracteres del apellido Lopez son idénticos a los de la estampa de la Dolorosa. Por otra parte, la calidad del paño pesado y grueso, propio de este grabador y que encontraremos en toda su obra, se hace aqui mas evidente por las características inherentes a una técnica más blanda como es la xilografía.

Su adscripción al neoclasicismo quedaría patente si fuera suyo, como pienso, un grabado existente en la colección del Museo. Presenta una nueva versión, grabada a punta seca, del Altar Mayor de la Capilla de la Animas de Santiago, diferente a aquel publicado por Bouza Brey ${ }^{12}$. Desgraciadamente la prueba es muy defectuosa, resultando ilegible la firma del grabador en el margen inferior derecho, donde parece adivinarse el apellido López. En el otro extremo se puede leer con dificultad Julian Dapalo (?) la retoco.

En la lámina se representa el Calvario con una ciudad al fondo, y en la parte baja dos ángeles tenantes sostienen un ovalo donde aparecen las ánimas. El marco es rectilineo y sencillo, sin ornamentación alguna, excluyéndose por completo la estructura del retablo y situando la escena sobre un paisaje.

En cuanto a su cronología no hay duda de que estamos ante una obra del 800.

Si comparamos esta calcografía con la estampa abierta a buril de la Virgen de los Dolores de San Miguel podremos apreciar ciertas semejanzas, fundamentalmente en lo que respecta a la representación del ropaje y al dibujo de los rostros de rasgos muy sencillos, meramente indicativos. Por otra parte resulta bastante torpe en cuanto a la representación del desnudo, como se puede ver en las figuras de Cristo, los ángeles y las ánimas. Hago notar también el hecho de que los carácteres gráficos de la leyenda grabada al pie de ambas ilustraciones parecen los mismos. No se aprecia, sin embargo, el punteado característico de nuestro grabador en rostros y zonas desnudas del cuerpo, lo cual podría deberse al desgaste sufrido por la plancha, pues como ya hemos apuntado, está visiblemente deteriorada.

Aun se pueden añadir al catálogo otras dos xilografías anónimas, una de

${ }^{12}$ F. BOUZA BREY: op. cit., 1964, pág. 209.

"CUADERNOS DE ESTUDIOS GALLEGOS", Tomo XL, Fascículo 105, Santiago 1992. 
las cuales ya había sido atribuida a Jacinto López por Filgueira Valverde ${ }^{13}$. En ella se representa a Santa Lucía coronada por un angel, sobre un paisaje con árboles y una capilla al fondo, rodeada de nubes y rayos -muy del gusto de nuestro autor- que surgen con la aparición del Espíritu Santo. Sin orla, la ilustración esta enmarcada por una doble línea recta que se rompe en las esquinas formando $C e s$ recortadas.

La atribución se basa en las semejanzas que he encontrado con los otros grabados, como es el tipo de plegado, el aspecto denso de las nubes, el rayado grueso y la torpeza del dibujo, sobre todo cuando se trata de realizar un desnudo, como podemos apreciar en la figura del angel que no está muy lejos de aquellos que ocupan las enjutas de la xilografía de la Virgen de Belen. En lo que respecta al gusto por el motivo de la $C$ recortando los margenes, y en conjunto toda la composición, nos recuerda la estampa de la Dolorosa de San Miguel.

La otra xilografía, cuya composición no se aleja mucho de esta, la encontramos ilustrando dos novenas, una impresa en Santiago en la Imprenta de Manuel María de Vila en 1828, y la otra, ya de mediados de siglo, en la Imprenta Antunez de Pontevedra.

Estamos aquí ante un grabado de pequeñas dimensiones $(7 \times 6 \mathrm{cms}$.) de marco cuadrangular que encierra un ovalo ocupado por la imagen de $\mathrm{La}$ Dolorosa. La Virgen se alza sobre un paisaje con dos cipreses y una iglesia al fondo (que nos recuerda inevitablemente al que vimos en la xilografía de Santa Lucía), en una actitud muy semejante a la de la Virgen del Altar de las Animas, pero en este caso con los brazos extendidos, los flancos superiores se cubren con masas nubosas, trabajadas en reticula, como la que aparece en el interior del timpano de la estampa de la Virgen de Belen.

No quiero insistir más en las características propias de este autor que ya señalamos repetidamente al tratar de otros grabados y que aquí se hacen manifiestas (rasgos del rostro, plegado pesado y grueso, etc.) ${ }^{14}$.

Conviene citar como cierre de este artículo las palabras de A. Rodríguez Moñino que, aunque referidas a un grabador de mas talla, expresan con gran acierto el carácter de la obra de Juan Crisóstomo López y tantos otros grabadores compostelanos: No estamos en presencia de un artista... sino de

\footnotetext{
${ }^{13}$ J. FILGUEIRA VALVERDE: op. cit., 1949, pág. 15, núm. 62.

${ }^{14} \mathrm{La}$ misma versión realizada por manos menos hábiles aparece en una novena reimpresa en Santiago, en la Imprenta de la Vda. de Campaña en 1847.
}

"CUADERNOS DE ESTUDIOS GALLEGOS", Tomo XL, Fascículo 105, Santiago 1992. 
un humilde artesano que con su buril contribuyó, en la pobre medida de sus fuerzas, a la propagación de imágenes y devociones estrictamente... compostelanas ${ }^{15}$.

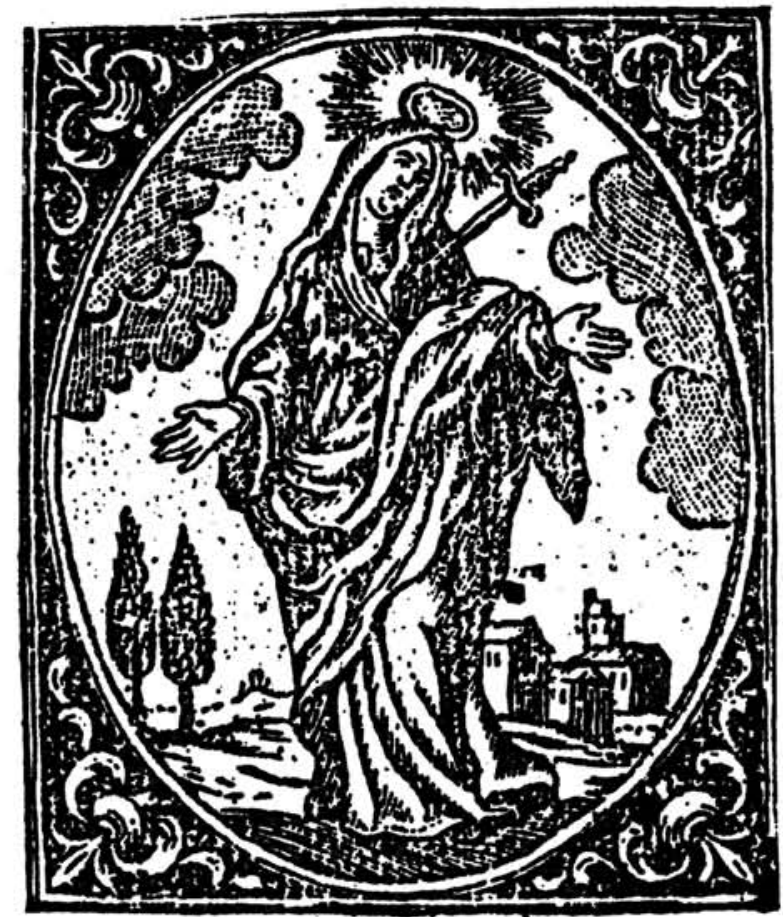

Virgen Dolorosa. De una novena editada en Santiago en 1828.

${ }^{15}$ A. RODRIGUEZ MOÑINO Y MARQUES DE LEDE: Diego de San Roman y Codina. Estampero sevillano del siglo XVIII. (1743-1789). Noticia y catálogo de sus obras. Boletín de la Sociedad Española de Excursiones, 1954, pág. 89 y ss.

"CUADERNOS DE ESTUDIOS GALLEGOS", Tomo XL, Fascículo 105, Santiago 1992. 


\section{CATALOGO*}

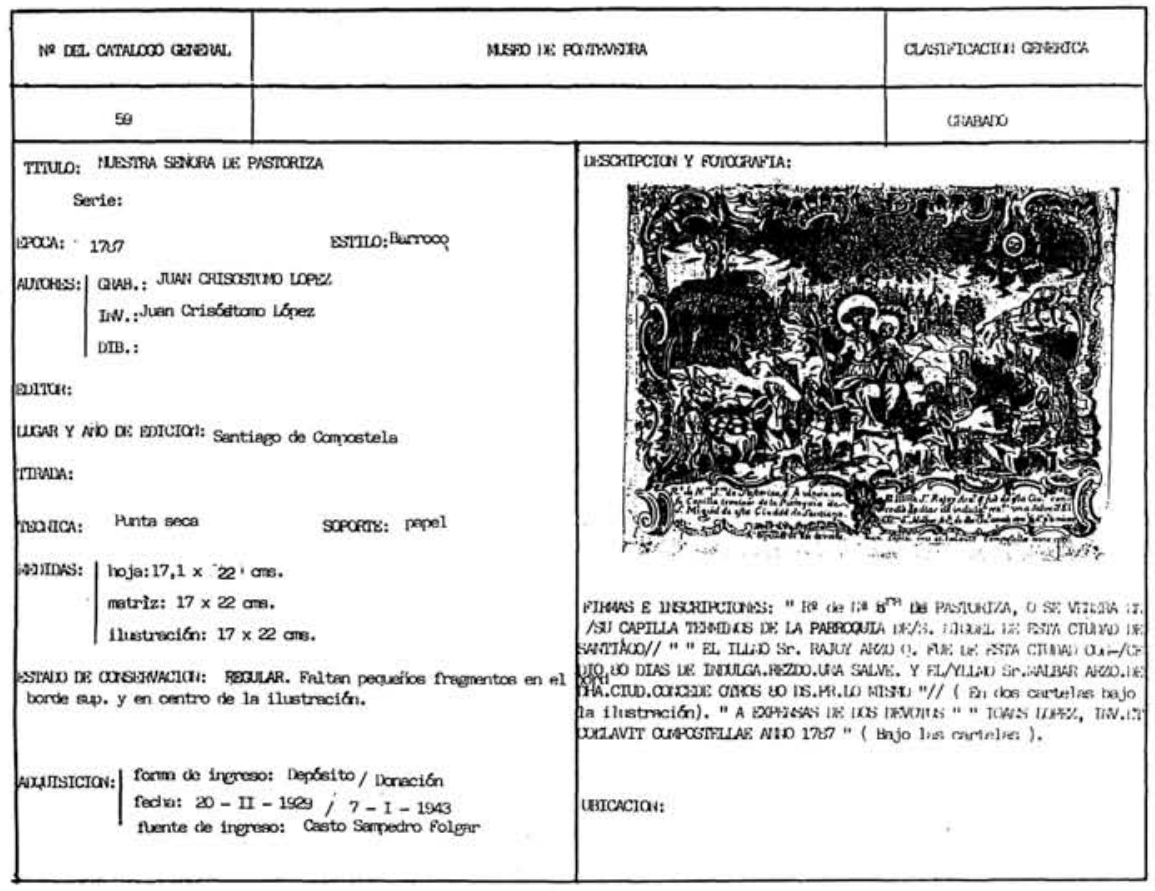

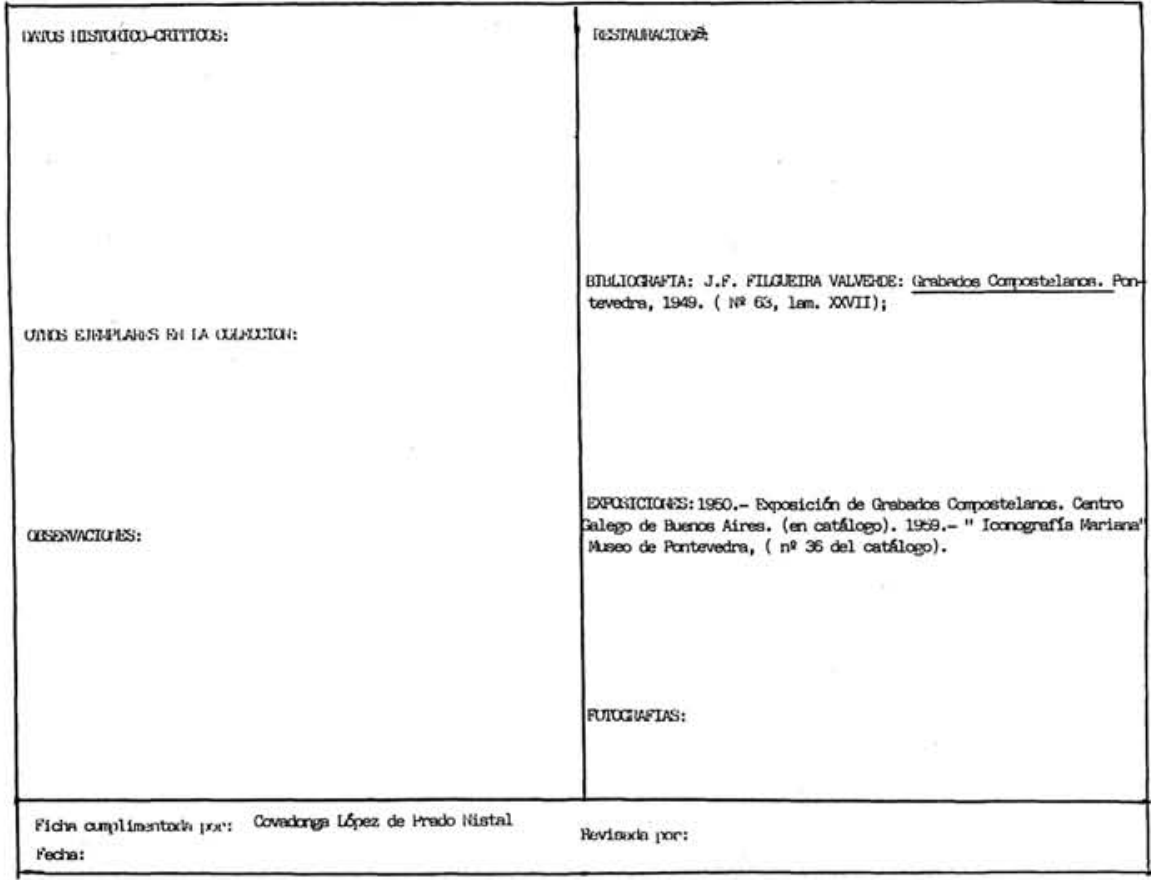

* Las fichas que presento no se corresponden con las del catálogo General del Museo de Pontevedra, sino que han sido diseñadas tomando como base el modelo de ficha del Istituto Centrale per Il Catalogo e la Documentazione de Italia. 


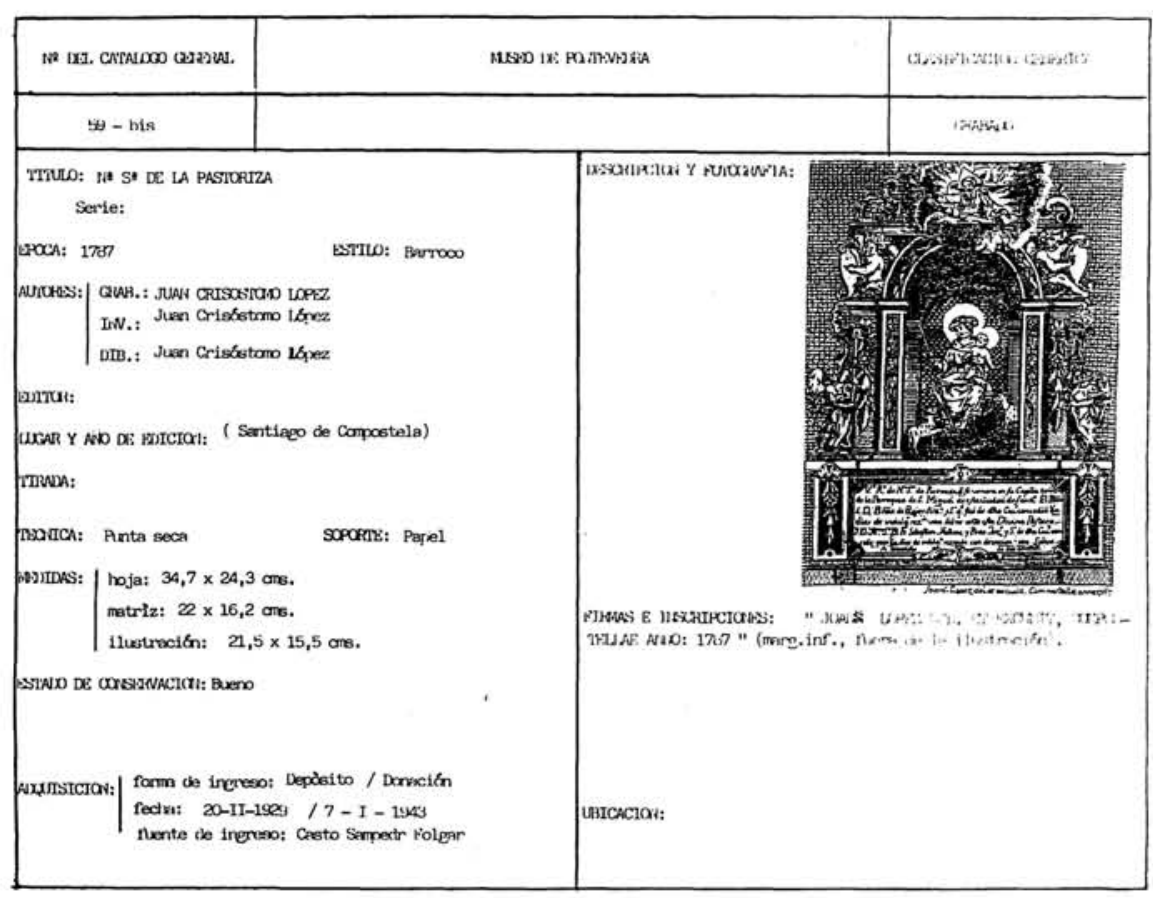

\begin{tabular}{|c|c|}
\hline 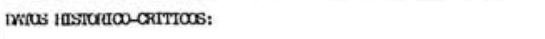 & 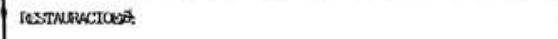 \\
\hline 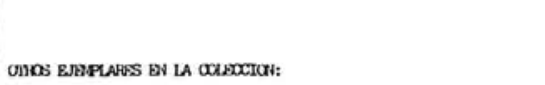 & 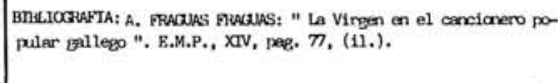 \\
\hline 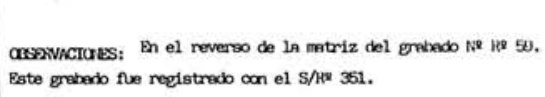 & 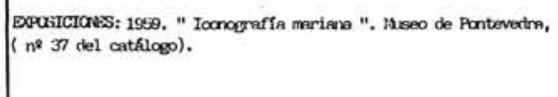 \\
\hline & Frucawris: \\
\hline $\begin{array}{l}\text { Ficha amplinentach por: Covarbnes Lojez de Prado tilstal } \\
\text { Pecha: }\end{array}$ & Revisach por: \\
\hline
\end{tabular}




\begin{tabular}{|c|c|c|}
\hline 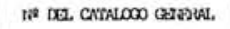 & \multicolumn{2}{|c|}{ 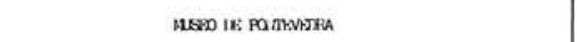 } \\
\hline $1.6002-22$ & & GLAASO \\
\hline 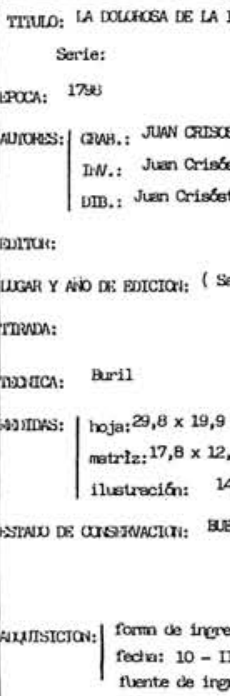 & 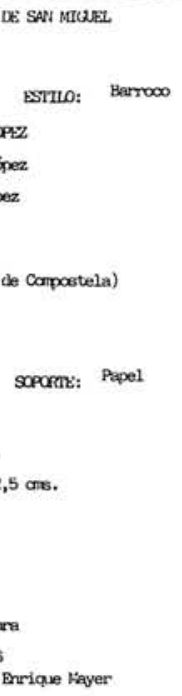 & 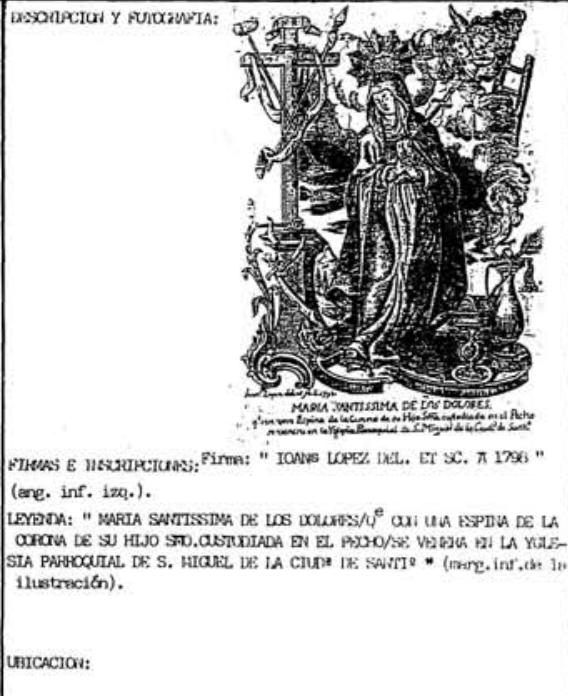 \\
\hline
\end{tabular}

\begin{tabular}{|c|c|}
\hline 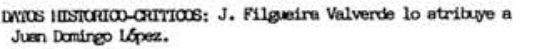 & reSTAURACICEST: \\
\hline 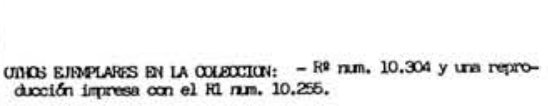 & 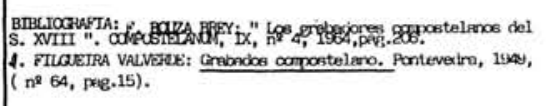 \\
\hline COSPRVACIOLS: & 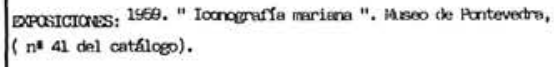 \\
\hline & EUIOCFAFIAS: \\
\hline 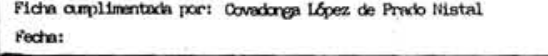 & ievisadh por: \\
\hline
\end{tabular}




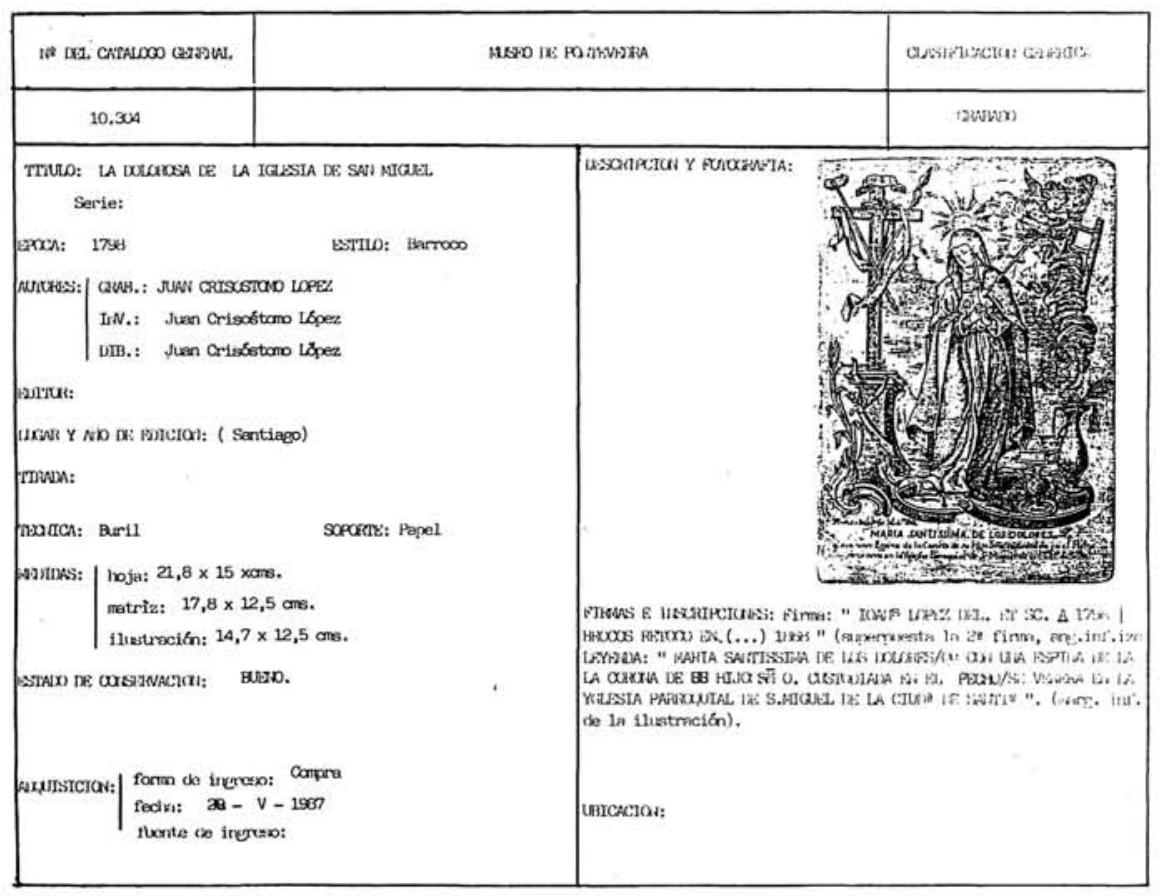

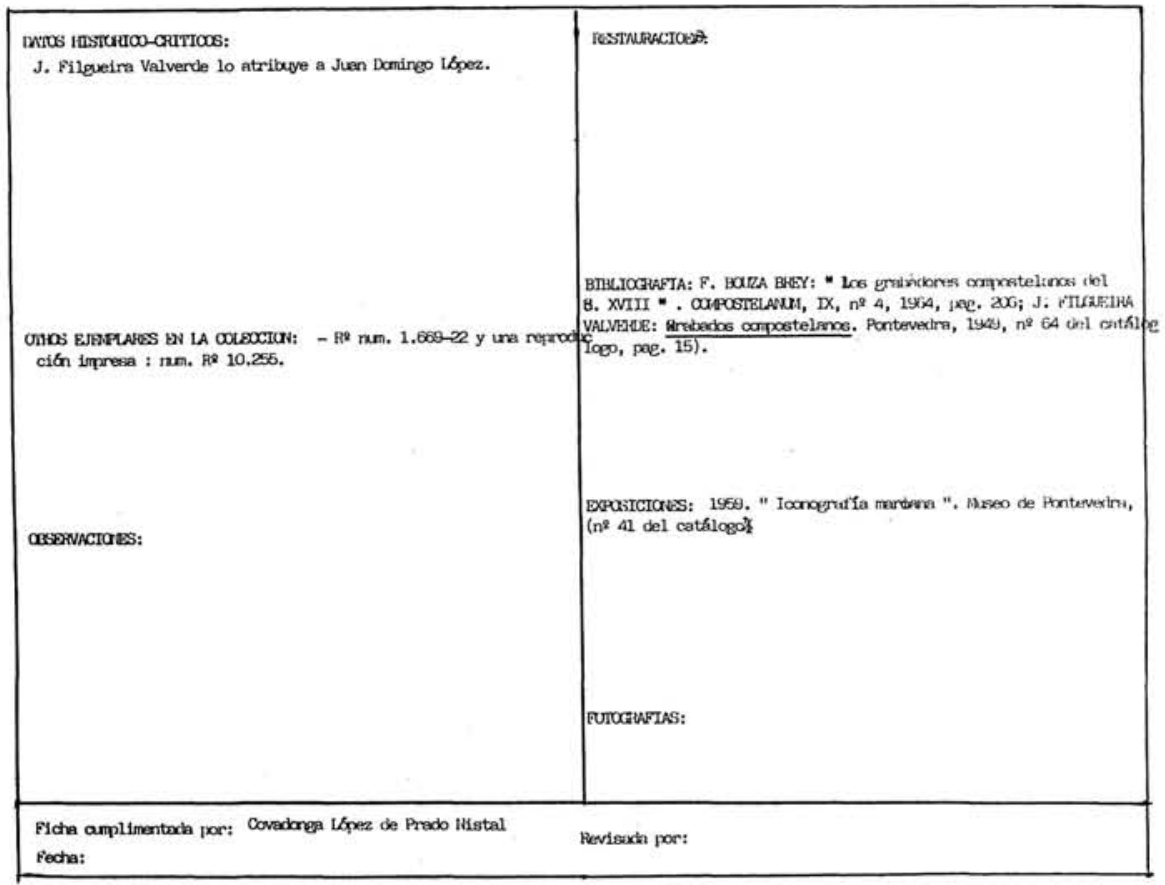




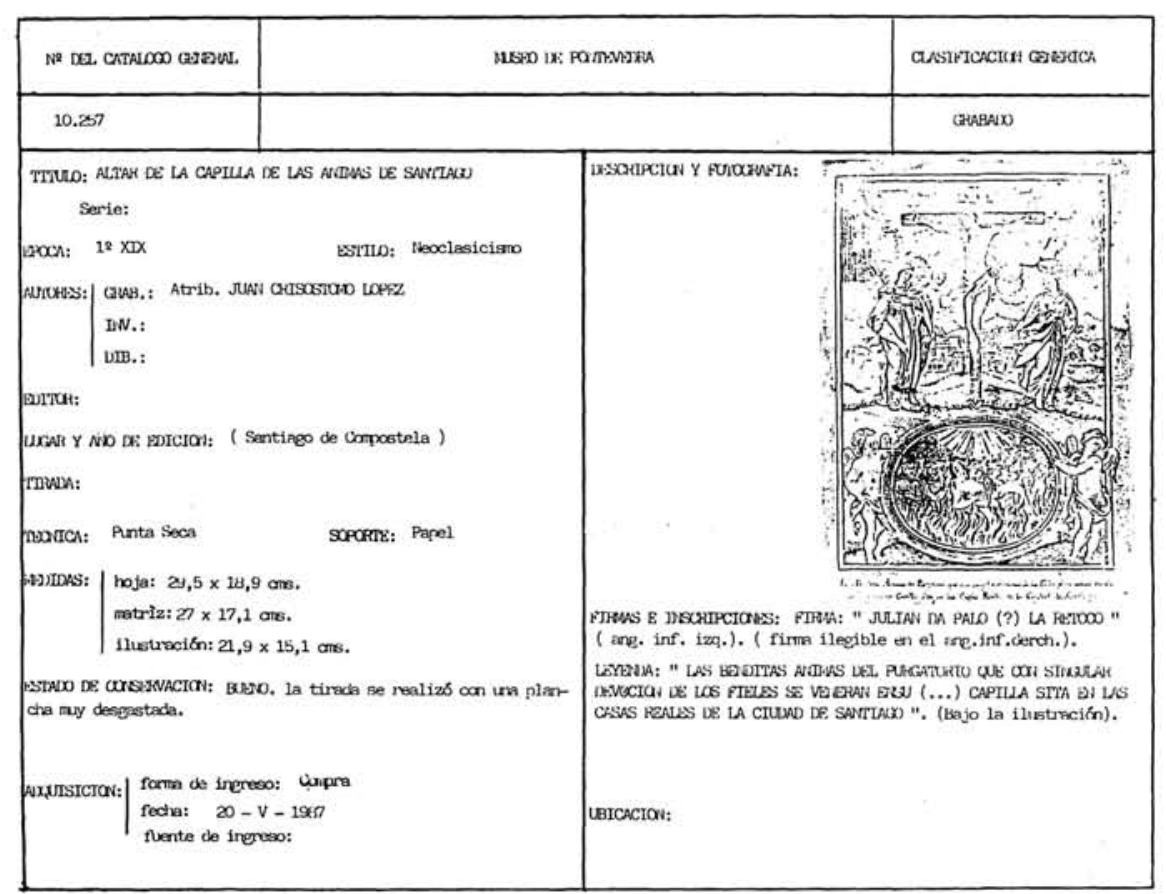

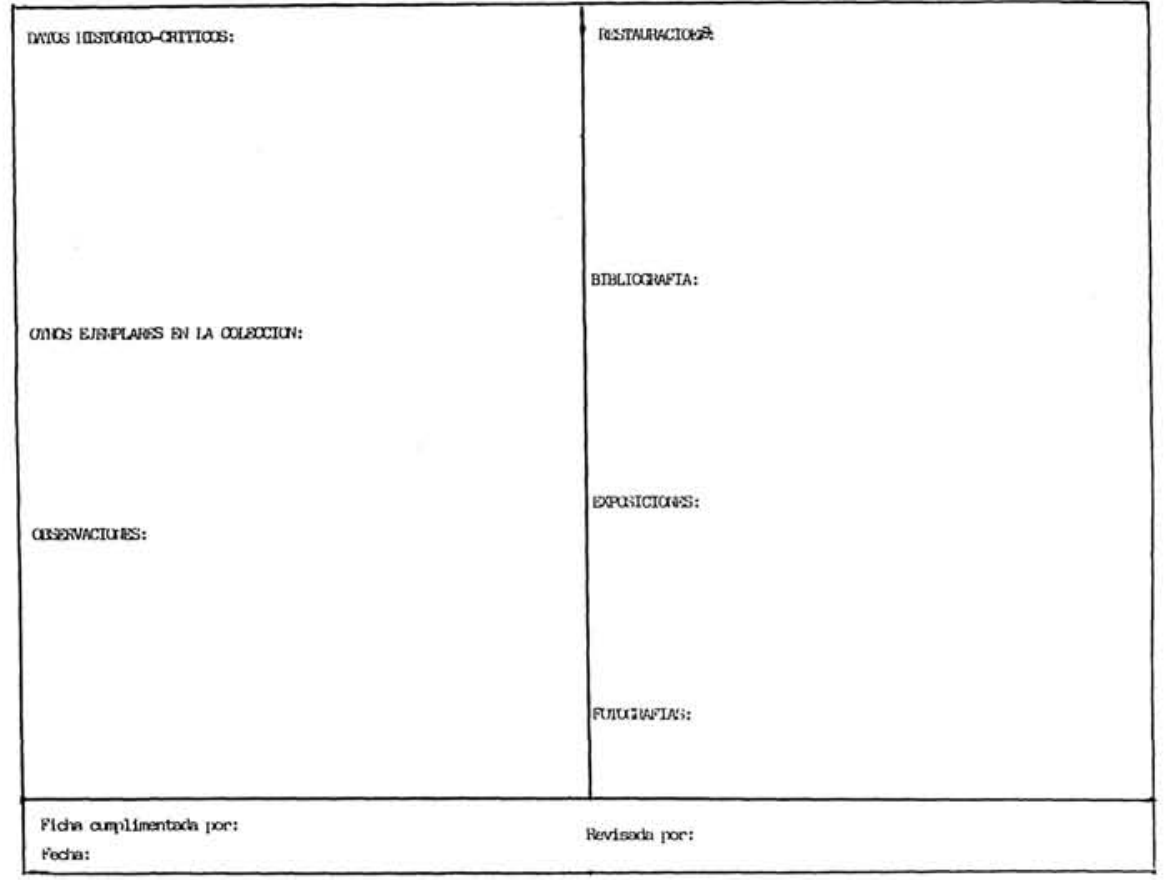




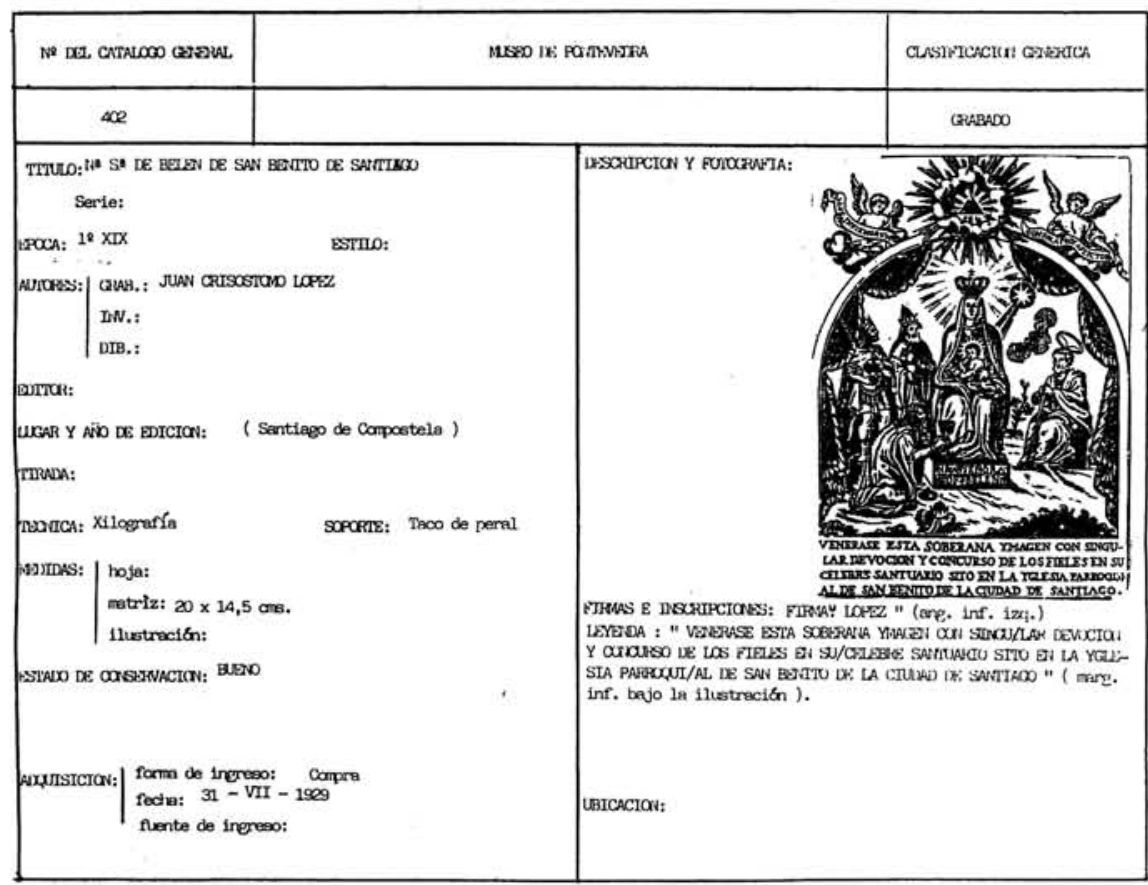

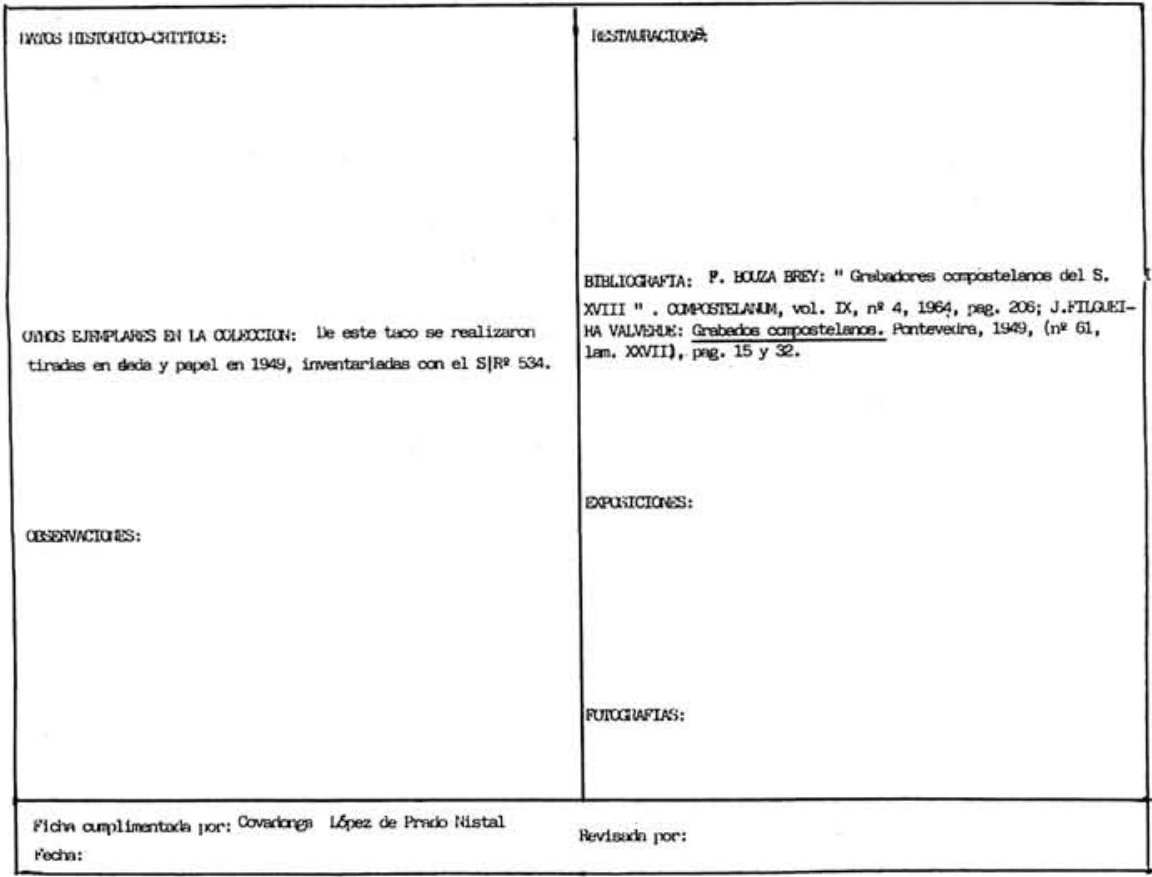




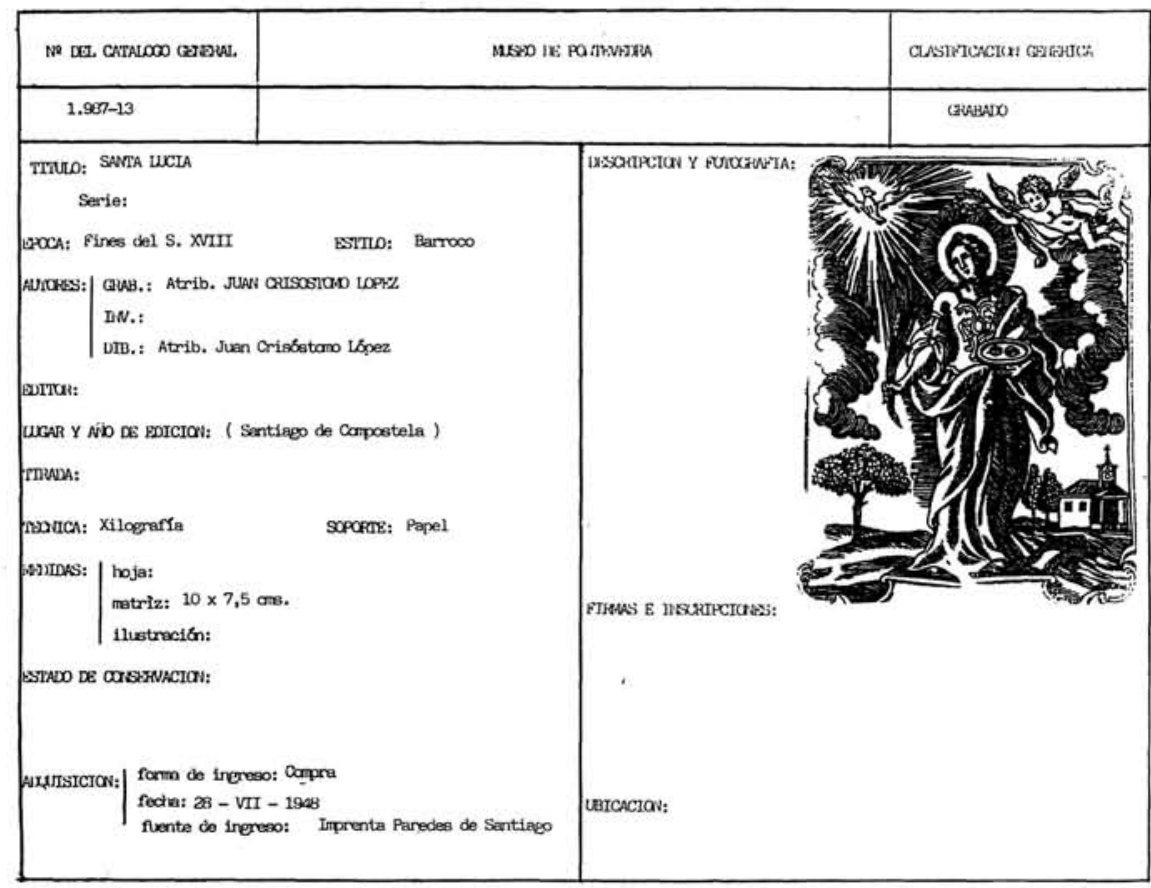

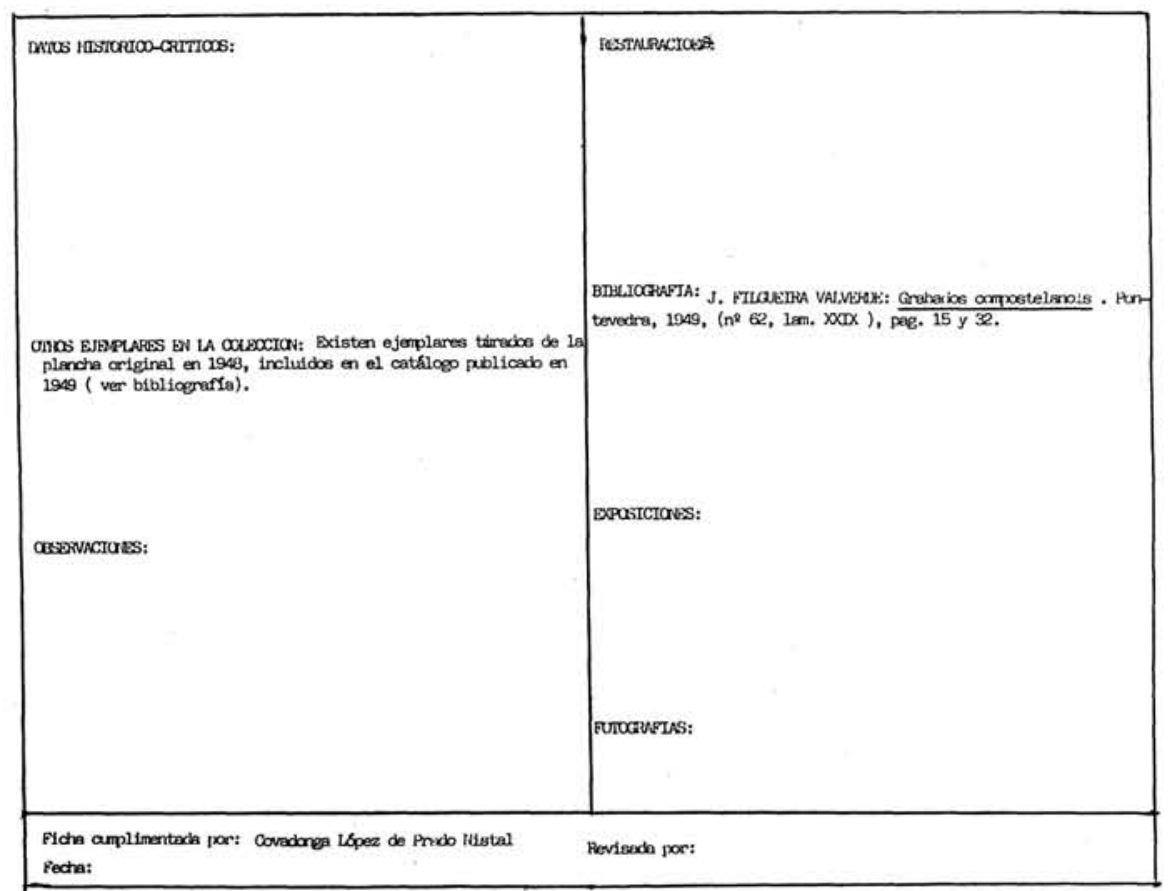

